Article

\title{
Applicability of Islamic Methodology Concerning Novel Issues to the Organ Transplantation in Religious Scholars' Contemporary Discourse
}

\author{
Faroque Amin (D)
}

check for updates

Citation: Amin, Faroque. 2021. Applicability of Islamic Methodology Concerning Novel Issues to the Organ Transplantation in Religious Scholars' Contemporary Discourse. Religions 12: 670. https://doi.org/ $10.3390 /$ rel12090670

Academic Editor: Terry Lovat

Received: 15 July 2021

Accepted: 16 August 2021

Published: 24 August 2021

Publisher's Note: MDPI stays neutral with regard to jurisdictional claims in published maps and institutional affiliations.

Copyright: (C) 2021 by the author. Licensee MDPI, Basel, Switzerland. This article is an open access article distributed under the terms and conditions of the Creative Commons Attribution (CC BY) license (https:// creativecommons.org/licenses/by/ $4.0 /)$.
School of Social Sciences, Western Sydney University, Liverpool, NSW 2170, Australia; faroque.amin@westernsydney.edu.au

\begin{abstract}
Classical Islamic theology has laid down a meticulous and intricate methodology of dealing with novel issues from theological perspectives; to understand and actualise religious viewpoints regarding any matter or event that did not take place during the early formative period of Islamic Shari'ah, i.e., the lifetime of the Prophet (S.). During the later formative period, classical Islamic scholars developed several principles such as Qiyas (analogical deduction), Ijma'(consensus), Istihsan (public interest), 'Urf (local norms) and so on, that all together would build the construct of the concept of Ijtihad (independent interpretation), and which would be carried out by competent religious scholars. Organ transplantation, of which organ donation is a conceptual component, is a contemporary issue that was not familiar among Muslim scholars in the early era. Therefore, it is the contemporary religious scholars' responsibility to address this matter and bring Islamic judicial inference into the discussion. In doing so, some of the scholars differ in opinions. This paper aims to offer an introductory survey of the religious viewpoints on this issue, as presented by leading scholars from different schools of thought. This study will also include the judicial principles they have adopted in reaching those opinions. By doing so, this paper will introduce an overview of current and ongoing theological discourse on the matter of organ transplantation and donation.
\end{abstract}

Keywords: islamic theology; Ijtihad; organ transplantation; organ donation

\section{Introduction}

An innate characteristic of any religion is that, being a belief system, it impacts the actual life of its followers. These impacts often differ between religions in varying degrees and from various dimensions. The nature of religion and the religiosity of its adherents both play roles in determining those impacts. A religious person or group usually seeks approval or legitimacy from the religious authorities in their day-to-day living matters. However, the impact and manifestation of the belief system on people's lives differ among religions and societies; Islam seems to have a more substantial presence in the Muslim communities.

In fact, in the wake of the 20th-century Islamic revivalism as an aftermath of the global Muslim experience of colonial rule, one of the slogans promulgated by the ideologues of these movements states 'Islam is a complete code of life'. Early revivalist scholars of the 19th century, such as Jamal al-Din al-Afghani (1838-1897) and Muhammad Abduh (1849-1905), focused on the aspects of rationality and the applicability of Islam in modern life. Their successors in the next century, such as Hasan al Banna (1906-1949), Syed Qutb (1906-1966) and Abul A'la Maududi (1903-1979), took one step forward and attempted to portray the religion as an autonomous civilisation by reclaiming the completeness of Islam. With time, that slogan has found a general acceptance among Muslims worldwide.

The primary reason for this acceptance is the motivation to return to the ideals of the early Islamic era. Muslims consider this era as a time when the basics of knowledge were completed. All later developments are viewed as further progress. 
The formative centuries of Islam clearly show that this religion continued through gradual progress to adapt to the changing times and places over the centuries, with a careful preservation process of its primary textual sources, namely the Qur'an and the Sunnah (prophetic traditions). The central force of this progress was Ijtihad (independent reasoning); the process of determining the religious views on any novel issue based on the revealed texts and other Islamic judicial principles.

Many centuries later, Muslim scholars started to agree to the point that all major religious issues had been settled. A phrase saying 'Ighlaq Bab al-Ijtihad' (closing the door of independent reasoning) appeared in texts around the end of the 9 th century. ${ }^{1}$ By this time, most religious scholars agreed that the era of Ijtihad (independent reasoning) was over, and the era of Taqlid (following/imitation) had begun.

The doctrine of modern revivalist Muslim scholars of Islam being a 'complete code of life' gently abolished this concept of the door of independent reasoning being closed, and extended the acceptance of Ijtihad in Muslim societies until the end of time. This paper aims to observe the application of Ijtihad in determining Islamic views on the Organ transplantation issue, along with introducing a comparative survey of these religious views as constructed by contemporary Muslim scholars.

\section{Shari'ah vs. Fiqh}

Before delving into the issue of Islamic views on organ transplantation, it is imperative to summarily mention the difference and association between two different terms, Shari'ah and Fiqh, to understand this issue's nature and place in Islamic discourse. One might say that organ donation and transplantation are an issue of Shari'ah, whereas another might see it as an issue of Fiqh. Although neither opinion could be described as wrong, one seems more appropriate than the other.

Shari'ah literally means 'the path to drinkable water'. In Islamic terminology, it denotes the whole religion given by God for his slaves, the human beings. It includes everything commanded, encouraged, discouraged and forbidden for them by the lawGiver. In the Qur'an, Allah said: "And then We set you, (O Prophet), on a clear high road in religious matters. So follow that and do not follow the desires of those who do not know" (Sura Jathiyyah (45): 18).

According to Islamic theology, the Shari'ah given to the last Prophet Muhammad (S.) ${ }^{2}$ is a continuation of all religious systems given to all the prophets before him. Therefore, the previous religions are also named Shari'ah in Islam, e.g., the Shari'ah of Moses, the Shari'ah of Jesus, etc. The word Shari'ah indicates religion in general, as it appears in a prophetic tradition narrated by Ibn Abbas, where the Prophet (S.) said: "Between Adam and Noah there were ten centuries and all of them (mankind) was on the shari'ah of truth. Later, when they differed, Allah sent the prophets and messengers" (al-Hakim 2002, vol. 2, p. 442).

According to the interpretations by scholars such as Hakim al-Nisapuri (933-1014), in this Hadith (prophetic tradition), the Shari'ah of truth (haqq) refers to a religion without idolatry or polytheism.

The word 'Fiqh' means knowledge or understanding. In theological terms, it denotes the knowledge of the ruling of Shari'ah regarding practical issues that are derived through elaborated evidence (Al-Mausuah al-Fiqhiyyah 1983, vol. 1, p. 13). In other words, it is the knowledge of Shari'ah ruling according to the texts of the Qur'an and Sunnah.

During the Prophet's lifetime, he provided religious rulings supported by revelation, al-Qur'an, and thus he was the primary source of Fiqh. Besides, he allowed people to go to other knowledgeable and qualified companions with their Fiqhi questions. Moreover, he sent such companions to different places as religious teachers and preachers.

After the Prophet's death, those scholar companions became the source of Fiqh and laid the foundations for later generations to construct the body of Islamic knowledge. The Qur'an and the prophetic traditions conjointly remained as the primary sources of Fiqh, as well as Shari'ah, since then. 
Based on this context, Shari'ah denotes broader and more general perspectives of religion, while Fiqh denotes specific knowledge of Shari'ah rulings or Islamic jurisprudence. Shari'ah cannot be changed as the whole religion is called the Shari'ah of Muhammad (S.), whereas Fiqh can be changed and developed based on new information and interpretations. Fiqh is usually associated with a pioneering scholar of a specific school of thought, for instance, the Fiqh of Abu Hanifa, the Fiqh of Shafe'i, the Fiqh of Ahmad bin Hanbal, the Fiqh of Malik, the Fiqh of Shi'a and so on.

To summarise, any religious issue can be an issue of Shari'ah. Still, not all would directly be associated with Fiqh, unless it invokes the matter of religious judicial standards such as permissibility or prohibition. In this sense, the issue of organ transplantation is an issue of Fiqh in a precise manner. However, in a broader sense, it is a Shari'ah issue as well.

\section{Ijtihad}

Ijtihad literally means to endeavour, to strive, to work hard, etc. In Islamic legal terminology, it means the process of finding out the religious rulings based on the sources of religion, i.e., the Qur' an and the Prophetic traditions. In brief, Ijtihad is translated as the process of independent reasoning for the issues of Fiqh.

As the famous Hadith describes, when the Prophet was sending a companion named Mu'adh bin Jabal as the ruler of Yemen, he asked Mu'adh how he would judge if a matter of dispute arose there. Mu'adh replied, "According to the Qur'an." The Prophet asked what he would do if he did not find the solution in the Qur'an, to which Mu'adh said he would judge according to the Sunnah. The Prophet thereupon asked him again what he would do if the answer was found neither in the Qur'an nor in the Sunnah. He replied, "Then I shall struggle to come to the best opinion and not spare any effort in doing so." The Prophet patted his back and told him he was right (Ash'ath 2008, vol. 4, p. 180).

In a simplified manner, it is famously said that the sources of Islamic Shari'ah, according to the Sunni schools of thought, are four; Qur'an, Sunnah, Ijma' (consensus) and Qiyas (analogy). However, an in-depth search in the scholarly works and theories of early and classical scholars may find more Shari'ah sources, broadly divided into two categories; primary and secondary sources.

Primary sources of Shari'ah are infallible as they were revealed. They are the Qur'an and Sunnah. Secondary sources are subject to changes depending on the interpretations of the primary sources, and according to the principles of Islamic jurisprudence (Usul al-Fiqh). These sources include Ijma' (consensus), Qias (analogical reasoning), Istihsan (juristic preference), Maslaha Mursalah (public interest), Ijtihad (reasoning), Istidlal (inference), 'Urf (local custom) and so on. The degree of the acceptance and performance of these secondary sources varies in different schools of thought (mazahib).

Hashim Kamali (Kamali 2008, p. 25), a prominent contemporary academic on the topic of Islamic law and jurisprudence, loosely incorporated all these secondary sources under the category of Ijtihad. According to him:

"Ijtihad means striving or exertion by the mujtahid (one who carries out Ijtihad) in deriving the rules of Shari'ah on particular issues from the sources. Normally such rules are not self-evident in the sources and their formulation necessitates a certain amount of effort on the part of the mujtahid. Ijtihad may consist of an interpretation of the source materials and inference of rules from them, or it may consist of an opinion regarding the Shari'ah ruling on a particular issue. Since the divine revelation has come to an end with the demise of the Prophet, Ijtihad remains the main instrument of interpreting the divine message and relating it to the changing conditions of the Muslim community."

Yusuf al-Qaradawi, an influential Egyptian Islamic scholar, described Ijtihad as a process of reasoning referenced by the revealed sources of Shari'ah, and carried out following the judicial principles by able Islamic legal scholars, who have reached specific standards (al-Qaradawi 1996). However, he emphasised that the increasing complexity 
of modern issues requires consultation with experts and specialists of different fields to perform Ijtihad soundly.

\section{Organ Transplantation}

Organ transplantation is the process where an organ is removed from a body and placed in another body to replace a damaged or missing organ. The objective of this process is to provide a functional replacement. Transplantable organs currently include some vital organs such as the heart, kidney, brain, liver, lungs, pancreas, intestine, etc. The kidneys are the most commonly transplanted organs globally, followed by the liver and the heart.

David Hamilton, a British transplant surgeon, mentions that, although the era of successful organ transplantation in its current understanding started in the mid-20th century, there were precedents in earlier times. Accounts of plastic surgery, to some extent, are found in surgical records from $600 \mathrm{BCE}$, and the issue of using donors' tissues appears in records from medieval times. Several images of the 3rd-century twin physician saints Damian and Cosmas in various shrines show them transplanting a human leg (Hamilton 2012). The concept is also mentioned in several science fictions from earlier times.

According to Thomas Schlich, the first successful human corneal transplant, which is considered a tissue transplant, was performed in 1905 in the current Czech Republic. Earlier to that, the first successful organ tissue transplantation, a thyroid transplant, took place in 1883. In 1954, the first-ever successful organ transplantation, a kidney transplant, took place in Boston, USA (Schlich 2010). Since then, technology has advanced rapidly and the medical science related to organ transplantation procedures has achieved several incredible successes.

Currently, this medical procedure continues to include more vital organs and intricate tissues. Organ transplantation provides hope and solutions for patients with the possibility of imminent death, extending their lives and returning them to healthy living for a more extended period. However, the practice of organ transplantation constantly has been confronted by moral and ethical debates. Medical practitioners, philosophers and intellectuals continue to address those issues in the quest for solutions.

\section{Muslim Response}

In the early years of Islam, becoming wounded on the battlefield was commonplace. In several prophetic traditions, it was mentioned that the Prophet (S.) replaced a lost eye of a companion, Qatadah ibn Nu'man, after the battle of Uhud, and an arm of another two companions after the battle of Badr. However, these historical events are not considered as the medical procedure of organ transplantation, and the Prophet (S.) never claimed them to be of any medical nature. Rather, these events in Muslim history are considered prophetic miracles or extraordinary abilities (Mu'jiza) as given by God only.

On the other hand, his companions and contemporaries were not given such miracles. Like any other ancient society, people with experience and ability conducted medical treatments according to their knowledge. Islamic theology never opposed the acceptance and necessity of such pragmatic knowledge. Muhammad Albar views that "Muslim jurists sanctioned transplantation of teeth and bones, which had been practised by Muslim surgeons from a thousand years ago" (Albar 2012). Early discussions about bone and teeth transplantation were found in some books of Muslim scholars such as Al Majmu' by Imam Nawawi (1233-1272) and Mughni al-Muhtaj by Imam al-Khatib al-Shirbini (d. 1570).

The most famous Muslim physician in history, Ibn Sina (1210-1288), considered bone transplantation "a hazardous operation that he would never attempt to perform" (Albar 2012). However, the modern understanding of organ transplantation is a novel medical procedure requiring Ijtihad (reasoning) to extract religious rulings.

Islam considers disease as a natural phenomenon (Sunan Kawniyyah), as well as a type of tribulation and process of expiating minor sins. At the same time, taking medication and other practical measurements for cure and protection are always encouraged, like any other natural phenomenon. Usama Ibn Shuraik narrated, “... O Messenger of Allah, 
should we seek medical treatment for our illnesses? He replied: yes, you should seek medical treatment, because Allah, the Exalted, has let no disease exist without providing for its cure, except for one ailment, namely, old age" (Tirmidhi 2007).

When this issue came into public consideration in the 20th century, Muslim scholars resorted to reasoning. Preserving human dignity is one of the vital objectives of Islamic law (Maqasid al-Shari'ah). As part of this objective, the human body, living or dead, has to be honoured. Therefore, mutilation of any dead body or any sort of disrespect for it is prohibited in Islamic law under any circumstance. However, the issue of performing postmortems or removing organs from a cadaver is considered from another legal perspective. In this case, the Maslaha (benefit) of saving a human life supersedes the harm, if any, done by organ removal. However, a living donor cannot provide an organ that would end his/her life. In this case, the principle of doing no harm takes priority.

As Ijtihad is a process of independent reasoning, outcomes can undoubtedly be different, called Ikhtilaf (disagreement). Some Muslim scholars, notably among them a popular Egyptian cleric Sheikh Metwali al-Sharawi (1911-1998), took a strong stance in 1988 against the permissibility of organ transplantation in Islam. His simplistic expression, "Our bodies belong to God only, so it's not yours to give", created a stir and gained popularity in many Muslim societies. This opinion gained popularity among the traditional Muslim communities worldwide. The argument was simplified enough for mass understanding. Moreover, the rejection of modernity was one of the inherent socio-religious characteristics of 19th and 20th century Muslim thought. This may have also helped this viewpoint gain more acceptance.

However, mainstream Muslim judicial scholars maintained a steady process of reasoning regarding the issue of organ transplantation. Starting in 1959, the Grand Mufti of Egypt allowed blood transfusion, and in 1966, not long after the first successful organ transplant procedure in the western world, the then Grand Mufti of Egypt allowed organ transplants. Later in various international conferences participated by the leading Muslim jurists from around the globe, organ transplant issues from Islamic perspectives were discussed elaborately and allowed in general with consideration of the restriction on relevant ethical issues such as organ selling or human trafficking for organ transplantation. National Islamic scholars' councils and boards of several countries such as Algeria, Kuwait and Saudi Arabic also announced religious rulings about the permissibility of organ transplantation. However, large swathes of Muslim societies remain resistant to the idea of organ transplantation. Lack of literature, discussion and publicity might have played a role in the existence of this phenomenon.

\section{Theological Principles and Opinions}

In Islam, a human is considered as the slave of the creator. Their body is not owned by themselves, rather it belongs to God. Based on this principle, neither suicide nor euthanasia is allowed in Islam. The same principle also prohibits selling any human organ alive or posthumously. Although a general consensus is established among contemporary Islamic scholars about the permissibility of organ transplantation by donation, provided that it meets certain conditions, some traditionalist scholars extend the same principle to interpret it as the reason for prohibiting organ transplantation in Islam. Consequently, a general rejection against the permissibility of organ transplantation in Islam remains prevalent, at least conceptually if not practically, among the Muslim masses. To address public resistance to organ transplantation, governments in different countries such as Malaysia, UK, Canada and Singapore have published pamphlets and brochures promoting the practice from an Islamic point of view.

The effect of this theological misconception, which is similar in all Muslim societies worldwide, is demonstrated in the experience of Sherine Hamdy, a US anthropologist who studied Egyptian society with a particular focus on the organ transplantation issue. She mentioned that the first kidney transplantation in Egypt was carried out in the mid-1970s, but the government and religious scholars could not clarify their standpoints until the 
late 1980s. However, when the stories of the exploitation of poor organ sellers and the problems faced by the organ recipients due to a non-existent legal framework started to come out in the media, the official religious scholars in Egypt declared the permissibility of organ transplantation in Islam. However, it soon became an issue of debate when Shaykh Sha'rawi, a famous religious scholar and television figure, stated that kidney donation is not allowed because 'it is not yours to give'. In this regard, Hamdy described her experience of a prolonged discussion with a pro-organ transplantation Shaykh (religious scholar) of al Azhar University. Although that scholar agreed with the permissibility of organ transplantation, he still dwelled in the philosophical aspects which, according to Sherine, seemed "worlds away from the predicaments of end-stage kidney-failure patients in the Tanta dialysis wards. He believed that if we were all certain about our place within God's plans of Creation and servitude, then none of these 'contemporary' questions would be ethically vexing" (Hamdy 2012, p. 54). In this abstract statement, the Shaykh preferred to accept fate as God's decision instead of finding a higher-level medical solution such as organ transplantation.

Medical technology has progressed rapidly over the last century, and the discussion of organ transplantation has become more intricate, to include questions and possibilities that were unknown previously. Naturally, the disagreement between Muslim scholars on these issues has also increased. However, most scholars have a general agreement about the acceptance of organ transplantation. Therefore, the opinion of organ transplantation's permissibility is attributed to the opinion of 'Jamhur' or the majority of scholars in current religious texts and books.

This 'majority' of religious scholars have exercised their 'ijtihad' authority to derive the permissibility of organ transplantation in Islam based on specific textual evidence and with some certain conditions. The characteristic of 'Ijtihad' as being the process of independent reasoning becomes evident when it is found that opposing scholars pondered upon the same textual evidence and reached a different outcome due to their unpermissive explanation.

The Qur'an states, "If anyone saved a life, it would be as if he saved the life of the whole people" (chapter 5: verse 32), "Allah intends every facility for you; He does not want to put to difficulties" (chapter 2: verse 185), "Allah desires that He should make light your burdens, and man is created weak" (chapter 4: verse 28) and "Allah would not place a burden on you, but He would purify you and would perfect His grace upon you" (chapter 5: verse 6).

In the prophetic tradition it is stated that one day, when the Prophet (S.) was sitting among his companions, a nomad person came to him and asked, "Oh Messenger of Allah, shouldn't we give ourselves medicine?" The Prophet replied, "Yes, oh slave of Allah! Give yourselves medicines. Allah has not created any disease without creating the cure for it, except one disease." The people asked, "What is that disease?" He replied, "Death" (al-Jawziyyah 1998).

Apart from these textual references, several Islamic judicial maxims were widely quoted by religious scholars to allow organ transplantations. These are "Removing harm is one of the objectives of Shari'ah", "When a matter becomes narrower, the solution becomes wider", "Necessity allows the prohibited" and so on. They also generally quoted the commonly agreed objectives of Islamic Shari'ah. One of those primary objectives is 'to protect the religion, life, intellect, wealth, dignity and lineage of a human being'. The scholars expounded that if protection of life required organ transplantation, then it would become permissible. (Athar 2015; Rady and Verhejde 2014; Shuriye 2011).

This permissibility comes with certain conditions. Islamic scholars categorise organ transplantation into two types: transplanting an organ from a living person, and transplanting an organ from a dead body.

There are some general conditions for the first category. First of all, the need for organ transplantation has to be an utmost necessity after exhausting all the other possible and available medical options. Moreover, the donor cannot be harmed in any way as a result 
of the procedure. The donor is also prohibited from receiving any material or immaterial reward at all. Finally, the transplantation cannot cause mixing in the lineage in any way.

For the second category, transplanting an organ from a dead body, the generally agreed-upon conditions are: the death has to be confirmed where there is no possibility of returning to life, the need of the organ receiver has to be extreme without any alternative, the deceased had provided their consent for organ donation in an entirely sound state of mind and voluntarily before their death and, finally, it cannot lead to a mixed lineage in any way, which means the transplantation of any active reproductive organ is categorically forbidden (al-Quradagi 1990; Bakur 2001).

On the other hand, arguments from the opponents of organ transplantation are based on the stricter interpretation of the same textual evidence. Instead of allowing the ease that can be implicated by those verses from the Qur'an and prophetic traditions, they state that these textual depositions cannot supersede the ownership of a human body by its creator. Additionally, to remove an organ for any other reason besides saving its holder's life is considered an act of desecrating what was initially created by God. Another argument proposed by the opponents of organ transplantation is based on the philosophical statement of body-soul integration. They claim that there is no separation between the soul and the body in Islam and, therefore, organ transplantation cannot be allowed, even when a person is clinically dead. However, the strongest argument is often the simplest one. The primary argument of the opponents is that organ transplantation cannot be allowed for the same reason as suicide being prohibited in Islam, a human being's soul and body is owned by God, and they are not allowed to violate them in any way (al-Quradagi 1990; Ali and Maravia 2020; Hurst 2016). To arrive at this conclusion, religious scholars holding the opposing views also exercised their authority of Ijtihad, or personal reasoning. Although the opposing views are broadly classified into two categories, more in-depth reasoning and interpretations resulted in more variation of opinions inside both of these broader categories. A religious scholar generally condoning the acceptance of organ transplantation in Islam may see a specific organ as non-transplantable, whereas other scholars may see it as being allowed to transplant.

\section{Major Literature}

In this section, I will briefly introduce the important books and authors on this topic in English and Arabic (two major languages of the Muslims), including the scholars of Islamic studies and other specialisations found through searching various libraries. ${ }^{3}$ This section aims to produce an introductory survey of the critical literature on this topic that needs more circulation among the religious scholars, with the ultimate objective of removing general assumptions from Muslim societies and increasing informed knowledge on this topic.

Abul Fadl Mohsin Ebrahim, an Emeritus Professor of Islamic Studies in South Africa, authored the earliest book found in English on Islamic views of organ transplantation. The book titled Biomedical Issues: An Islamic Perspective was published first in $1988 .{ }^{4}$ Later, he wrote several books on Islamic aspects of relevant areas such as medical research, euthanasia, cloning, animal experimentation and reproductive health. The earliest book found in Arabic was written by Abdul Salam Abdul Rahim al-Sukary and titled Transfer and Transplantation of Human Organs: A Comparative Study from Islamic Viewpoint. ${ }^{5}$ Two books are currently in wide circulation among Arabic readers: Fighi Issues of Human Organ Transplantation ${ }^{6}$ was written by Ared Ali Aref, an Iraqi professor of Islamic Studies in the International Islamic University Malaysia, and published in 2010; and Organ Transplantation in Islamic Shari'ah Perspective $e^{7}$ was written by Yusuf Qaradawi, a Qatar-based Egyptian Islamic scholar, also in 2010. An international conference on organ transplantation in 2009, organised by the Centre of Islamic Research of Al-Azhar University, ${ }^{8}$ preceded both publications.

In English, a plethora of literature on Islamic viewpoints on organ transplantation is available. Still, it seemingly fails to reach the Muslim masses and traditional Muslim 
scholars in many countries and languages. Islamic Bioethics: Problems and Perspectives, ${ }^{9}$ authored by Dariusch Atighetchi, ${ }^{10}$ contains a chapter outlining the circumstances relating to the organ transplantation issue in numerous Muslim countries. The book Contemporary Bioethics: Islamic Perspective ${ }^{11}$, published in 2015 and jointly authored by Mohammed Ali al-Bar ${ }^{12}$ and Hassan Chamsi-Pasha, ${ }^{13}$ discusses Islamic viewpoints on different medicalrelated issues including organ transplantation. Islam and Biomedical Research Ethics ${ }^{14}$ by Mehrunnisha Suleman ${ }^{15}$ was published as recently as 2021 and explains the role of institutional forms of Islamic religious texts, scholars and their legal edicts in biomedical issues in Muslim countries. While discussing their topics, all these authors write about the widespread incorrect assumptions among Muslim communities in different parts of the world about Islamic viewpoints on organ transplantation.

It should be noted that a large number of Muslims in this era of the Internet attempt to gather preliminary information through internet search engines. A basic search shows that many popular online fatwa and Islamic resource websites such as islamqa.info, aboutislam.net (previously onislam), fatwa-online.com, islamcity.org, islamway.net and islamweb.net have some materials regarding Islamic views on organ transplantation. There is a typical pattern of focusing on 'donation' instead of 'transplantation' visible in most online materials. However, many other major and popular Islamic websites have nothing on this issue, as well. Finally, numerous academic journal articles published in recent years have focused on some Islamic aspects of organ transplantation. However, they are primarily out of the reach of the general population.

\section{Conclusions}

An elementary survey of the existing literature demonstrates a general absence of religious literature regarding the Islamic viewpoints on organ transplantation. However, publications on this topic authored by intellectuals from different areas have appeared in recent years.

According to Islamic theology, not everyone can express religious viewpoints without achieving such authority by gaining certain qualifications and standards. A scholar has to reach some specific higher standards of Islamic knowledge before they attempt to perform independent reasoning. Regarding a complex issue such as organ transplantation, advice and consultation would be sought from specialists, but the attempt should be initiated and carried out by religious authorities. Common misconceptions and misunderstandings regarding organ transplantation prevailing in Muslim societies will not be abolished unless the religious scholars come forward with verbal and written contributions.

Among the books and essays written by Islamic scholars on organ transplantation, a trend of increasing acceptance is observable with the continuation of time. The texts published in the 2010s have a less rigid approach towards this issue than the books published in the 1990s or earlier. However, they generally continue to emphasise a few factors. The primary objective of the legitimacy of organ transplantation in Islam rests on the humanitarian cause and welfare of other human beings and the community. Many scholars consider this issue of such importance that they have demanded that the state or a board of medical experts be involved in organ transplantation processes so as to not take this matter lightly nor make it easily available.

This article summarises Muslim scholars' viewpoints on organ donation and transplantation, with a particular focus on the influence of Islamic Shari'ah's 'Ijtihad' framework to demonstrate its impact on this issue of Fiqh. Further research will include the schools of thought of those scholars, focusing on the impact of their schools on their reasoning or 'Ijtihad' outcomes.

Overall, organ donation in Islam can be a very complex issue. The theological authority in Islam is constructed upon a multidimensional structure of individual vs. collective scholarship as well as a diverse knowledge framework. When a novel issue is not unanimously agreed upon among Muslim scholars, it is not allowed to be judged as wrong or right. The Prophet said that the scholar practising 'Ijtihad' or reasoning may reach the right 
or wrong conclusion. As long as they have the intention to reach the truth, both will be rewarded. Therefore, the Muslim masses have the absolute right to follow their scholars if they consider their reasoning correct.

The Ijtihad framework in Islamic Shari'ah can be progressive and obstructive at the same time, depending on the religious scholars' interpretation frameworks. It keeps the possibility of both acceptance or rejection open and, therefore, also keeps the flexibility alive. Islamic scholars who allow organ transplantation in Islam have practised their Ijtihad authority by analysing the textual evidence. However, a small number of scholars holding opposing views also base their opinion on textual evidence. In most cases, they are the same texts with different interpretations. As rigidity and orthodox views are generally considered of a more religious nature among the masses, this comparative reality remains unknown to many Muslims. As a result, a great number of general Muslims are not aware of the fact that the majority of contemporary religious scholars consider organ transplantation as allowed in Islam, with some certain conditions. One of the most common suggestions found among the proponents of organ transplantation in Islam is to raise awareness about organ donation and transplantation among the masses so that they do not assume religious edicts based on their common knowledge of religion.

Funding: This research received no external funding.

Institutional Review Board Statement: Not applicable.

Informed Consent Statement: Not applicable.

Conflicts of Interest: The author declares no conflict of interest.

\section{Notes}

1 Wael B. Hallaq (1984) conducted an extensive research on this topic titled 'Was the gate of Ijtihad closed?'.

2 This refers to the Arabic phrase 'sallallahu alaihi wa sallam', meaning 'peace be upon him', which is preferable in the Islamic Shari'ah to add after mentioning the Prophet Muhammad (S.).

3 The libraries searched for this purposes were the library of International Islamic University Malaysia (https:/ /lib.iium.edu.my / (accessed on 15 June 2021)), the library of Western Sydney University (https:/ /library.uws.edu.au/main/ (accessed on 15 June 2021)), the library of Islamic University of Madinah (https:/ / www.iu.edu.sa/site_Page/104923 (accessed on 15 June 2021)) and the WorldCat library catalogue website (https:/ / www.worldcat.org/ (accessed on 15 June 2021)).

4 Published in Kuala Lumpur by the A.S. Nordeen Publishing House.

5 This book was found on the library websites of the Islamic University of Madihan and the International Islamic University Malaysia, but no information about the book or the author was available.

IIUM Press, Kuala Lumpur.

Dar al-Shuruq, Cairo.

For more details, please see: https: / www.iifa-aifi.org/ar/2787.html (accessed on 15 June 2021).

2007, Springer, The Netherlands.

An Italian professor of Islamic Bioethics and Theology at the Second University of Naples.

Springer, London.

Director of Medical Ethics Centre in the International Medical Center, Jeddah, Kingdom of Saudi Arabia.

A cardiologist at King Fahd Armed Forces Hospital, Jeddah, Kingdom of Saudi Arabia.

Routledge, Oxon and New York.

A postdoctoral researcher at the Centre of Islamic Studies in University of Cambridge.

\section{References}

Albar, Mohammed. 2012. Organ transplantation: A Sunni Islamic perspective. Saudi Journal of Kidney Diseases and Transplantation 23: 817-22. [CrossRef] [PubMed]

al-Hakim, Muhammad ibn Abdullah. 2002. Mustadrak 'Ala al-Sahihain. 5 vols. Beirut: Dar al-Kutub al-Ilmiyyah, vol. 2.

Ali, Mansur, and Usman Maravia. 2020. Seven Faces of a Fatwa: Organ Transplantation and Islam. Religions 11: 99. [CrossRef]

al-Jawziyyah, Ibn al-Qayyim. 1998. Zaad al-Ma'aad fi Hadyee Khairil 'Ibad. Beirut: Muassatur Risalah, vol. 4.

Al-Mausuah al-Fiqhiyyah. 1983. Al-Mausuah al-Fiqhiyyah, 3rd ed. 45 vols. Kuwait: Ministry of Islamic Affairs, vol. 1.

al-Qaradawi, Yusuf. 1996. Al-Ijtihad fi al-Shari'ah al-Islamiyyah. Kuwait: Dar al-Qalm. 
al-Quradagi, Aref Ali Aref. 1990. Qadaya Fiqhiyyah fi Naqli al-A'da al-Bashariyyah. Kuala Lumpur: IIUM Press.

Ash'ath, Imam Hafiz Abu Dawud Sulaiman bin. 2008. Sunan Abu Dawud. Riyadh: Darussalam, vol. 4.

Athar, Shahid. 2015. A Gift of Life: An Islamic Perspective in Organ Donation and Transplantation. Journal of Transplantation Technologies E Research 5: 2161-991. [CrossRef]

Bakur, Kamal al-Din Jumah. 2001. Hukmul Intifa' bil A'da al-Bashariyyah wal Haywaniyyah. Beirut: Dar al-Khair.

Hamdy, Sherine. 2012. Our Bodies Belong to God: Organ Transplants, Islam, and the Struggle for Human Dignity in Egypt. California: University of California Press.

Hamilton, David. 2012. A History of Organ Transplantation: Ancient Legends to Modern Practice. Pittsburgh: University of Pittsburgh Press.

Hurst, Daniel J. 2016. Approaching Organ Transplant in Islam from a Multidimensional Framework. Online Journal of Health Ethics 12: 8. [CrossRef]

Kamali, Mohammad Hashim. 2008. Shari'ah Law; An Introduction. Oxford: Oneworld Publications.

Rady, Mohamed Y., and Joseph L. Verhejde. 2014. The moral code in Islam and organ donation in Western countries: Reinterpreting religious scriptures to meet utilitarian medical objectives. Philosophy, Ethics, and Humanities in Medicine 9: 1-9. [CrossRef] [PubMed]

Schlich, Thomas. 2010. The Origins of Organ Transplantation: Surgery and Laboratory Science, 1880-1930. New York: University of Rochester Press.

Shuriye, Abdi O. 2011. Muslim Views on Organ Transplant. IIUM Engineering Journal 12: 203-8. [CrossRef]

Tirmidhi, Imam Haifz Abu Eisa Mohammad. 2007. Jami at-Tirmidhi. Riyadh: Darussalam. 